\title{
Metonymi hos Jacobsen
}

\section{I}

Georg Brandes skrev - i sit bekendte 'digterportræt' af Jacobsen - om romanen Fru Marie Grubbe: „Desværre er der ingen anden rigtig Enhed og Sammenhæng i Bogen end den som de optrædende Personers Forhold til Heltinden afgiver. Heltindens Levnet er den Snor, paa hvilken de løse Billeder ere trukne«. ${ }^{1}$ Senere i samme forbindelse skriver han om titelpersonen i Niels Lyhne:»Denne føres ganske som Heltinden i den tidligere Roman gennem en Allé af Bipersoner - det er den eneste Art Komposition, der falder Jacobsen naturlig. $\|^{2}$ Hvad Brandes ser som mangel i de to romaner, er en sammenkædning af handlingselementerne i motiverede forbindelser, der bygger op til konklusioner. ${ }^{3}$ Hverken handling eller hovedpersoner udvikler sig. Her finder man hverken peripeti eller anagnorisis, kun scener og deskriptioner i seriel rækkefølge; som træer på række i en allé, som 'løse billeder' på snor. Dog forhindrer Brandes' modvilje ikke, at han registrerer, hvordan Jacobsens prosa i stedet hænger sammen: »Alt er fortættet, sammentrængt, uden Fyld eller Mellemrum. ${ }^{4}$ Efter et citat fra en karakteristisk deskription - „Derude, uden for Vinduet, rødmede de som Roser, de hvide Blomster, i Skæret fra den synkende Sol« - skriver Brandes: "Stilen i disse Landskabs- og Blomstermalerier kommer det metriske Foredrag nærmere end den gode Prosa gerne gør, og er, som man sér, rent lyrisk. $\|^{5}$ Men omvendt hedder det også om de få digte i forfatterskabet: „I deres Form er de kun lidet afvigende fra hans Prosa.» Og han tilføjer: „Et formfast, regelmæssigt tilbagevendende Versemaal vilde det være Jacobsen umuligt at komme tilrette med«. Brandes afslutter med, at Jacobsen i virkeligheden udelukkende var »Prosadigter«, hvilket i portrættets kontekst da får en for-

1. Citeret efter Georg Brandes: Samlede Skrifter, Tredje Bind, Kbh. 1900, p. 20.

2. Op.cit., p. 29.

3. Brandes skriver om det, han savner i Jacobsens fortællen: »at den ved Gentagelse, Modstilling, fornyet Eftertryk, Udvikling eller Uddybning af det éngang Givne bidrager til at befæste og samle Fantasibillederne paa lignende Maade som man i en videnskabelige Afhandling gør det ved Sammenfatning af Hovedpunkter«, op.cit., p. 21.

4. Op.cit., p. 3 .

5. Op.cit., p.10. De efterfølgende citater p. 11. 
holdsvis præcis betydning. Nemlig en forfatter, som hverken følger prosaens eller den metriske lyriks endnu på det tidspunkt sædvanlige former, men som digter frit i noget, der følgelig ligger prosaen - den mest åbne form nærmest. Men Brandes' beskrivelse er mere overbevisende end hans forklaring: Jacobsen »er for moderne« - »han vil, at Formen paa ethvert Punkt skal rette sig efter Følelsen, Stemningen, Indholdet«.

Jeg skal i denne artikel forsøge en anden slags tilgang, nærmere betegnet en undersøgelse af, måske ikke hvorfor, men af hvordan den særlige jacobsenske prosalyrik eller lyriske prosa alligevel har både bevægelse og sammenhæng trods dens åbne mangel på egentlig 'komposition' på de niveauer af teksten, Brandes har sit øje rettet imod. Hænger de 'løse billeder' alligevel sammen? Hvad er det, der gør, at teksten kan klare sig uden »Fyld og Mellemrum«?

Når man foretager analyser af realistisk prægede tekster med fiktive personer, omkring hvilke en kæde af handlinger er organiseret, møder man en tydelig afstand mellem det tematiske niveau og det niveau, hvor tekstens handlende personer udfolder sig. Det sidstnævnte niveau - personerne og deres handlinger i et mere eller mindre realistisk fiktionsrum - vil typisk danne ramme for vores umiddelbare oplevelse af teksten, sådan som der tydeligt også er tale om for Brandes' vedkommende. Men også for en mere moderne læsning vil person- og handlingsniveau være et naturligt udgangspunkt, hvorfra man med afsæt i forløb og karakterer efterfølgende søger at støde frem til de dybereliggende tematiske lag. Denne mulighed vil byde sig til i forbindelse med Jacobsens romaner og noveller, der for de flestes vedkommende præsenterer både karakterer, handling og realistiske fiktionsrum. Men hvor flertallet af tekster i den lidt ældre litterære tradition som regel giver analytikeren chancen for på et tidspunkt at få niveauerne til at mødes, så volder Jacobsens prosa på det punkt problemer. Forløbet viser sig i romanerne, som Brandes rigtigt så det, blot at være protagonistens passage gennem en 'allé af bipersoner' og tilmed en allé, som ender blindt. "Så døde han da Døden«, som der - i Niels Lyhnes slutning - står i den danske litteraturs eneste anvendelse af dette karakteristiske verbum, som om det kunne være transitivt: en transitivform, hvis funktion først og fremmest synes at være at skjule eller lukke for en »Udvikling eller Uddybning af det éngang Givne, " som ikke er der. Også en karakterorienteret analyse af de protagonister, der er lige så elusive som forløbet, vil - og i høj grad af samme grund hurtigt føre væk fra tekstens interne forhold og ud i hypoteser om psykologien bag teksten, hvorom det i dette tilfælde heller ikke er let at sige noget præcist, hvis ellers man vil påtage sig det ærinde at prøve. ${ }^{6}$ Det har således sine årsager, at Jacobsens prosa har givet anledning til så divergerende analy- 
ser og så mange analyser, som stadig synes at lade de dyberegående spørgsmål om prosateksternes interne bevægelsesdynamik stå åbne. ${ }^{7}$

Men Jacobsens forfatterskab indeholder også i et lille antal prosadigte, tekster uden protagonister, uden blinde 'alléer af bipersoner', ja uden gennemgående personer overhovedet. Også et umiddelbart sammenhængende og lokaliserbart fiktionsrum kan mangle. Når dertil kommer, at selv rimene er forsvundet og metrummet er afløst af rytmen i såkaldte 'frie vers', så står man for alvor over for en jacobsensk tekststreng 'i rå tilstand.' En sådan tekst er digtet »Arabesk til en Haandtegning af Michel Angelo«. Åbenlyst sammenhængende på niveauer, som har at gøre med billedsprog og deskription, men uden gængse læserhåndtag til at løfte låget, så man umiddelbart kan se tematikken og sammenkædningsmåden bag billedsprogets staser af stemning. Teksten er tilmed litteraturhistorisk central ved at være et af de første danske digte, der for alvor giver sig i kast med de 'frie vers', og som gør det med et resultat, der med rette har givet det klassikerstatus. Digtet har da også været gjort til genstand for analyse adskillige gange, uden at det dog på nogen måde forekommer 'udtømt'. Lad os se, hvad der kan komme ud af en tilgang, der på forhånd afstår fra at søge eller rekonstruere det personniveau, der tydeligt mangler.

\section{II}

Selv om "Arabesk« i en grad, der er usædvanlig for tiden, lader hånt om konventionelle indikationer i retning af personer, handlinger og fiktionsrum, så kan digtet naturligvis ikke undgå at situere sig udsigelsesmæssigt. Men selv på det punkt drejer det allerede i selve anslaget på højst usædvanlig vis. I stedet for konventionelt at levere læseren det minimum af information, der skal til for at etablere blot en foreløbig udgangshypotese for forståelsen af det, der vil følge, starter det med at spørge og rejse tvivl, endog om sit eget indledningsspørgsmåls udsigelsesmæssige status. Er den første linie - „Tog Bølgen Land?« - og den uddybende gentagelse i de følgende tre linier således spørgsmål, som en fiktiv person stiller? Stilles de til en anden fiktiv person,

6. Flere har i tidens løb villet forsøge. Frederik Nielsen beskriver i J.P.Jacobsen. Digteren og mennesket. En littercer undersøgelse, Kbh. 1953 på biografisk grundlag Jacobsen som 'algolakniker'. Jeg har selv i Interieur fra det 19. århundredes borgerlige kultur, Kbh. 1976, søgt at sætte forfatterskabets psykologi i sammenhæng med generelle social- og familiehistoriske forhold i perioden. Torben Grodal har i sit portræt af Jacobsen i Gyldendals Dansk litteraturhistorie, bd. 6, Kbh. 1984 læst forfatterskabet som udtryk for provinsstudentens problemfyldte møde med hovedstadskulturen.

7. Man her nævne den vifte af indbyrdes meget forskellige analyser af novellen »Et Skud i Taagen«, som fremlægges i Anders Østergaard (red.): Skud, Kbh. 1992. 
eller er det et såkaldt retorisk spørgsmål? Er det et implicit, lyrisk jeg, som henvender sig til læseren? Eller måske til sig selv? Retorisk indebærer tekstens førstelinie en apostrofe, men hvad eller hvem der apostroferes står åbent.

Da der i en tekst som denne ikke er faste genrekonventioner til at styre læsningen, kan et svar kun søges i anslagets kontekst med det efterfølgende. Vers 5's svar - „Nej! Den stejled' som en Ganger« - peger i retning af et lyrisk jegs dialog med sig selv. Men det er ikke en indre dialog eller en dialog, der inden for et fiktionsrum skal forestilles at foregå inde i en fiktiv person. Det er snarere en 'retorisk' indre dialog hos et lyrisk jeg, der har læseren som medhører, og som indirekte henvender sig nok så meget til denne som til sig selv.

Hvad spørger dette jeg da om, og hvad svarer det så? Både spørgsmål og svar er imidlertid bredt beskrivende mere end de er præcise og logiske modsvar til hinanden. $\mathrm{Og}$ allerede de to første liniers anaforer og demonstrative allitterationer og assonanser anslår et suggestivt gentagelses- eller spejlmotiv, der næsten alene i spørgmålenes repetitive ordlyd indeholder et svar på et niveau hinsides det niveau, hvor en blot normalsproglig mening kommunikeres: Tog (v. 1) og Tog (v. 2), Land (v. 1), Land (v. 2) og Langsomt (v. $2)$. Vers tres »Rallende« tilføjer en tydelig dødskonnotation til den bevægelse, der beskrives. I efterdønningen herfra bliver det følgende »Grusets Perler» ladet med elementer af et kirkegårdsbillede, mens den følgende linies indledende »Atter" på ny lukker af med gentagelsen.

Spørgsmålenes bredt deskriptive svarsekvens, der fylder resten af første strofe, rykker imidlertid med en transformation hele betydningsfeltet, opretter et fiktionsrum og udfylder det med figurer i en lang dynamisk bevægelse, der rækker videre og følger parallelt med læsebevægelsen gennem de efterfølgende strofer. Transformationen eller metamorfosen indledes med en sammenligning: "Nej! Den stejled' som en Ganger«. Derefter viser 'den' bølgen - sig ikke kun 'som' en ganger, men at blive til en ganger. Gangerens manke og bølgens skum flyder visuelt sammen til ét billede - „Gjennem Manken gnistred Skummet - hvorefter 'den' fortsætter metamorfosen til en svanes ryg - »Snehvidt som en Svanes Ryg" - for endelig via en sidste forskydning at finde "Svanevinger», på hvilke 'den' kan flyve gennem solens hvide lys. Disse kæder af billedsproglige konstruktioner i stadig forandring er både usædvanlige og interessante. Billeddannelsen er først og fremmest styret af elementernes syntagmatiske og associative nærhedsrelationer: gangeren bliver til billede på bølgen, manken til billede på gangeren, skummet til billede på manken, svaneryggen til billede på skummet, vingerne til billede på svanen. Jeg vil foreslå at betragte disse billeder som metonymier. 
Tilsammen danner de en kæde af metonymiske metamorfoser, kunne man sige.

Indholdsmæssigt gælder det, at de dels levendegør et naturfænomen: bølgen rejser sig som en ganger og flyver derefter som en fugl gennem luften. Dels løsriver metamorfoserne det, der starter som bølgen, fra én bestemt skikkelse og gør den til et abstrakt 'den' eller 'det'. Hvad 'den' eller 'det' egentlig står for er imidlertid ganske vanskeligt at svare på, netop fordi det gennem sine metamorfoser unddrager sig et fast betydningsindhold. Dog kan man konstatere, at det i alle sine former er et naturfænomen, fra bølge til svane. Og en association til en forestilling om det biologiske liv i sin bredeste almindelighed og dets begyndelse i havet forekommer ikke urimelig som hypotese. En Darwin-farvet evolutionsteori i en ultrastram fortætning kunne overvejes, så meget mere som digterens bekendte Darwin-studier foregik netop i årene omkring digtets tilblivelse. ${ }^{8}$

Imidlertid bør en sådan kulturhistorisk, intertekstuel læsning ikke føre analysen bort fra digtets indre sammenhæng, der er fuldt af så mange selvetablerede betydningsmønstre, at en læsning af teksten som blot en darwinistisk allegori vil være en meget 'tynd' og for så vidt utilfredsstillende analyse. Ikke engang den tydeligt strukturerede natur med dets adskilte vand-, land- og luftrum lægger strengt taget op til det. Det er en generaliseret, men genkendelig naturverden, der fremstilles, med en række kosmiske, sydlige eller i hvert fald soldominerede billeder: "Straalestøv og Regnbu'taage« (v. 9), »Solens hvide lys« (v. 14). Og handlingsforløbet i strofen 'den' der rejser sig som en bølge og til sidst flyver på svanevinger ind over land - er så markant, at analysen må inddrage også det narrative aspekt, til trods for at de handlinger, der finder sted, ikke udføres af konkrete eller navngivne personer, men af et 'den' under stadig metamorfose. Den manglende eller ganske svage antropomorficering af de dynamiske aspekter gør, at det narrative aspekt kun kan håndteres i en billedsprogligt og tematisk orienteret tilgang. Bevægelsen i teksten har karakter af tematiske transformationer indlejret i billedsproget, ikke af en personbåret handlingskæde. Men bevægelse og forløb er der, allerede her i de første linier en bevægelse - båret af 'den' - fra vandbilleder til luftbilleder. Der foregår også en bevægelse i form af en lydlig forskydning fra a-lyde til i-lyde i beskrivelsen: som vand er 'den' "rallende«, som luft er 'den' "sitrende«. Overgangen ses på ny i den mærkelige gentagelse: »Ham den kasted',/ Ham den skifted'“, og lydparret går igen flere steder: i »Ganger» (v. 5) og »Bringe« (v. 6) og allerede da 'den’

8. Digtet blev første gang offentliggjort i Vilh. Møllers tidsskrift Flyvende Blade i juli 1874. Noget af digtet menes at stamme tilbage fra 1870. En beskrivelse af de forskellige kladder til digtet findes i Morten Borups udgave af J.P. Jacobsen: Samlede Varker, Kbh. 1928, bd. IV, p.161 f. 
bliver til »Manken«, får vi "gnistred« (v. 7) med en spejlvendt an-lyd over for en ni-lyd. Til sidst samles a-i modsætningen inde i ordet »Svanevinger« (v. 13), hvorfra $v i$-elementet fortsætter i sidste linies »hvide» (v. 14). Til sidst fastholdes i det efterfølgende »Lys $y$ fortungevokalernes 'lyse hvidhed', som slutpunktet på den forbindelse tilbage til vand og land, der er løbet gennem a-erne i kæden ganger, manke, ham og svane.

Sådanne lydlige mønstre er naturligvis betydningsmæssigt upræcise. Men de er i høj grad med til suggestivt at forstærke de narrative og tematiskbilledsproglige strukturer, når de kobler sig herpå i virksomme parallelliteter. Dog kan man også i metaforerne iagttage flere ændringer parallelt med dem, der i naturbillederne ligger i overgangen fra bølgen til svaneflugten. Så snart bølgen rejser sig fra vandelementets repetitive rallen, indføres nemlig et sæt helt nye størrelser. De er fra dyreriget - hest og svane men samtidig indføres de i konnotationsrige benævnelser og former: den stejlende »Ganger« (v. 5), den våde »Bringe« (v. 6), den gnistrende manke (v. 7) og endelig svanen, der i sig selv er et selektivt valg blandt flyvende væsener. Specielt med den stejlende 'ganger' anslås en romantisk forestillingsverden og bag den en middelalder- og ridderkonnotation, der med 'hamskiftet' derudover indlægges i et folkeviseunivers. ${ }^{9}$ Der bliver her trukket ud i ganske bestemte historiske og litteraturhistoriske registre, der langt overlejrer den blot darwinske evolutionsforestilling, som 'dens' opstigning fra havet kunne bringe i tankerne.

Det gælder i endnu højere grad i den efterfølgende lange strofe, hvor første strofes overgang fra den oceaniske natur til et middelalderligt og ridderligt forestillingsrum fortsætter i en videre udvikling til et mættet, dunkelt italiensk renæssanceunivers med lidenskabeligt-dramatiske scenerier, en billedverden à la den, der findes hos malerne Poussin og Claude Lorrain. ${ }^{10}$ Men strofeskiftet indleder også nogle interessante udsigelsesmæssige markeringer. 'Den' bliver nu igen til 'bølgen', og hvor den i første strofe blev omtalt i 3. person, bliver den nu direkte apostroferet af et explicit jeg: »Jeg kjender din Flugt, du flyvende Bølge« (v.2). Første strofes spørgende præteritum, der selv efter svaret opretholder en svævende uvished om hvad der egentlig sker, afløses nu af en meget indikativisk futurum, der fra en ligeledes ny fortælleposition dømmende forudsiger den videre skæbne for det, der søgende, anende rejste sig fra havet. Over for første strofes spørgsmålstegn

9. Det vil være nærliggende at nævne folkevisen »Germand Gladensvend«.

10. Det billede, digtet suggerer, er ikke et renæssancebillede 'malet efter naturen', snarere et fantasilandskab, en såkaldt 'capriccio': en tænkt lokalitet, der på ét sted rummer alle de elementer, man ønsker at forestille sig, uafhængigt af, om der i den virkelige verden findes et sådant sted, man kunne male over. 'Capriccio'-genren opstod i italiensk maleri i starten af det 17. århundrede. Cf. Ekkehard Mai (red.): Das Capriccio als Kunstprinzip. Zur Vorgeschichte der Moderne, Milano/Wien 1996. 
står anden strofes "vil«i både vers 2,3 og 5 . Samtidig efterfølges apostrofen imidlertid af en ny slående prosopopeia: »Men den gyldne Dag vil segne« (v. 2). Troperne har i første strofe, knyttet til de gentagne sammenligninger, et tydeligt metaforisk præg: "stejled' som en Ganger». I anden strofes vedholdende associative sammenkædning af billeder bliver metonymiske relationer imidlertid stadig mere dominerende. Dagen, der segner, er som synekdoke den mindre hyppige 'helhed for del' - en metonymi, ligesom den bliver en ny handlende størrelse $\mathrm{i}$ et metonymisk forhold til bølgen. Og det er ligeledes en metonymisk bevægelse, når dagen efterfølgende bliver »svøbt i Nattens dunkle Kappe« (v. 3). Med disse prosopopeia - dagen, senere »han« (v. 6) og natten - kommer det temporale aspekt i forgrunden, og i tiden ligger allerede 'faldet' oven på første strofes opstigning: dagen vil »segne« (v. 2) og bagefter »lægge sig træt til Hvile« (v. 4). Disse døds- og afslutningsbevægelser bliver i en ny metonymisk relation gentaget af omgivelserne: »Duggen vil glimte i hans Aande,/ Blomsterne lukke sig om hans Leje« (v. 5-6).

Der ligger en deskriptiv bredde i over fire vers (v. 3-6) at gentage, hvad allerede vers 2 har udsagt. Bredden til trods er deskriptionen imidlertid uforandret indlejret i en korrekt, normalsproglig prosasyntaks: »..den gyldne Dag vil segne/ [....]/ Først [her med betydningen 'inden'] du naaer dit Maal« (v. 7). Men denne meget karakteristiske konstruktionsmåde bliver bredt længere ud og spændt endnu hårdere op i resten af strofen. Syntaktisk indrammet af 8. vers" »- Og har du naa't det gyldne Gitter« og v. 23’s »Da forgaaer du i Anelsers Angst« ligger 15 liniers repetitiv deskription. Og i resten af strofen, hvor "Bølgen døer mellem Vinrankens Løv« (v. 26) og vinrankens drueklaser i strofens sidste linie på samme vis »Fældes ned i Havens Græs« (v. 33), gentages konstruktionen endnu engang. Gennem strofens i alt 33 vers tilføjes der handlingsmæssigt intet til vers 2 's »vil segne«. Til gengæld kvalificeres den ene bevægelse, der er tale om - bevægelsen mod døden igennem de deskriptive gentagelser i mange dimensioner, samtidig med at selve den fatalistiske deskription og dens gentagelsespræg ekkoagtigt, men fyldigt matcher indholdet i verberne »vil segne», "forgaaer du« (v. 23), »brændes op« (v. 24), »du døer« (v. 26), »fældes ned« (v. 33).

Den prosopopeia, der indledes med første linies apostrofe af bølgen, viser sig som begyndelsen til en mere omfattende ændring i det beskrevne univers. Ikke kun 'dagen’ og 'natten' bliver levendegjort, også duggen og derefter et flor af blomster træder til: blomsterne lukker sig (v. 6), magnolien har øjne, der blinker og stirrer (v. 13-14), irissen hvisker hemmeligt (v. 15), geraniernes duft dysser (v. 17), tuberosernes og jasminernes ånder tungt (v. 18), silken vugger sig (v. 30) og til sidst vrider vinrankerne sig angstfuldt. Hvor bølgen i første strofes hav- og luftunivers var det eneste handlende element $\mathrm{i}$ en ellers tom, øde natur, ankommer den ved sin flugt ind over land til 
et yppigt kultiveret univers, hvor den straks omringes af en tæt, tungtåndende havenatur. Verbalkonstruktionerne med bølgen som subjekt glider over i passiv. Det er omgivelserne, der nu agerer med bølgen som genstand for deres handling. Bølgens aktive verber er karakteristisk begrænset til »forgaaer« (v. 23), "glider frem« (v. 25) og »døer« (v. 26). Dog er der ikke kun en kontrast ved, at agensforholdet skifter bort fra den stejlende bølge. Samtidig sker der gennem strofen en oscillerende metonymisk forskydning mellem bølgen og omgivelserne: vers 2's segnende dag forudgriber selve bølgens død i versene 23 og 26, ligesom denne bagefter bliver gentaget ved, at de drueklaser, som bølgen dør i, selv fældes ned i græsset. Også statisk spejler bølgen og omgivelserne sig: den dør i »Anelsers Angst« (v. 23), ligesom dens dødsleje er de »angstfuldt vredne Ranker« (v. 32). Dette peger videre frem mod den anden tematiske ændring, at ikke kun optræder nu i strofe 2 en række personficerede naturfænomener, men alle bliver disse elementer - bølgen inklusive - nu psykologisk bestemte. Hvor det i første strofe var den animalske kraft, der som ren natur rejste sig i den stejlende ganger, har vi nu kun »en Luftning fra Havet«, der lander og forgår i »Anelsers Angst« og »skjælvende Længsel« (v. 24). Parallelt hermed er beskrivelserne skiftet fra visualitet og lys til duft og mørke som sensorisk dominerende. Det er også et skift fra morgen og begyndende dag med dens udfarende handling til dagen på hæld over mod nat med "graadmilde Drømme« (v. 16) og med gardinet, der "Langsomt vugger sig i tunge Folder« (v. 30). Den »rallende« død, der blev negeret i starten af første strofe ved bølgens rejsning, nærmer sig nu på ny, idet luftningen nedfældes i vinløvet.

Som indledningsvis berørt skifter fiktionsrummet også karakter fra første strofes natur- og middelalderpræg til et kulturunivers med præg af renæssance eller måske snarere manierisme eller barok. Planter og blomster (laurbærtræer, myrter, magnolier, geranier, tuberoser, jasminer, cypresser, vinranker) signalerer en klassisk farvet mediterran civilisation. Netop civilisationsaspektet er fremtrædende. Rummet er en aristokratisk havearkitektur med 'gyldent gitter' omkring, "Brede Gange« (v. 10) og i midten »den hvide Villa« (v. 19) omgivet af en »Vagt af høje, dunkle, / Høje, rolige Cypresser« og med »Balkonens Marmortærskel« (v. 28) som grænsen til villaens indre. ${ }^{11}$ Marmortærsklen, den højtbeliggende balkon og den høje, dun-

11. 'Villa' forstået som landbolig er et antikt fænomen, men forestillingsmaterialet her er tydeligvis den aristokratiske villa, som den genskabtes i renæssancen, hvor samspillet med havearkitekturen blev dyrket med stor interesse og historiske resultater til følge. Selv om digtets sceneri naturligvis er en 'capriccio', finder man renæssance- og manieristiske villaog haveanlæg, der helt lever op til dets forestillingsverden, eksempelvis Villa Gamberaia i Settignano, Villa d'Este i Tivoli og Villa Aldobrandini i Frascati. Cf. eksempelvis Torsten Olaf Enge \& Carl Friedrich Schröer: Garden Architecture in Europe, 1450-1800. From the villa garden of the Italian Renaissance to the English landscape garden, Köln 1990. 
kle cypresvagt omkring indikerer aristokratisk fornemhed, men også uudgrundelighed, hvortil endelig kommer den side af marmoret, der peger mod sarkofag og død. Det sidstnævnte aspekt bekræftes og uddybes i »Balkongardinets kolde Silke« (v. 29) og dettes vuggen »i tunge Folder« (v. 30). Villaen er som en tungt silkedraperet sarkofag med æresvagt omkring. Men igen er det ikke blot noget enkelt årsagsforhold, når bølgen, der er blevet til en ængsteligt fremadglidende luftning, dør under mødet med de vinranker, der draperer villaen yderst. Dens død på villaens ydre er lige så meget en gentagelse, en parallelitet til villaens indre. Den type metonymisk metamorfose, der antydningsvis skildres i starten af strofen, hvor bølgen bliver til 'dagen', gennemspilles da også her i strofens slutning mere udtrykkeligt. Luftningen, der dør i »Vinrankens Løv« (v. 26) synes nemlig at transformeres til »de gyldne Drueklaser« (v. 31), der fra deres »angstfuldt-vredne Ranker« (v. 32) dør på ny, idet de nedfældes i havens græs. Det er en dobbelt død. Men dermed ikke en endelig, tværtimod.

I digtets tredje strofe sætter et fuldt orkester ind. Alle billedsproglige virkemidler bliver gjort aktive, alt hvad der er blevet efterladt og afsluttet, vækkes igen til live i en mærkelig kombination af fremadskriden og tilbagegreb, dynamik og repetition med nogle variationer, der tilføjer lige så meget, som de gentager. Den konventionelle tids- og rumlogik, som i de beskrevne metamorfoser er blevet overskredet, bliver nu helt sat ud af kraft. Til gengæld træder en underliggende tematisk sammenhæng og et komplekst sæt af billedsproglige forbindelser tydeligere frem end nogensinde før.

Hvor luften som et overgribende dynamisk element forbandt første strofes vand og anden strofes land, er det i tredje strofe 'ilden' der fra først til sidst dominerer billedsproget: »Glødende Nat!«indleder strofen, og »du glødende Nat« afslutter den. Netop ilden er også aksen i den føniks-lignende genopståen, som bølgen oplever. Skønt den i anden strofe »Brændes op«i "skjælvende Længsel« og i et logisk eller realistisk kohærent fiktionsunivers dermed skulle være væk - så meget mere som den senere i strofen gennemløber endnu to dødsprocesser - er 'den', bølgen, i sin inkarnation som tredje strofes 'ild' mere intens end nogensinde før i sine vand- og luftformige skikkelser. Men den kohærens, som føniks-metamorfosen her trodser på fiktionsplanet, er til gengæld virksom på andre planer. Ligesom bølgen i sine tidligere former blev lokaliseret gennem en apostrofe, bliver den det nu igen som "glødende Nat«: »Langsomt brænder du henover Jorden« (v. 2). Og bag om bølgens metamorfose opretholdes i andre henseender alligevel en kohærens: fra anden strofes bevægelse, der endte i »Havens Græs«, fortsætter tredje strofe - »henover Jorden«-på samme niveau. Og hvor anden strofe løb gennem dagen frem til natten, så ligger tredje strofe i dyb nat. De "graadmilde Drømme«, "Anelsers Angst« og »Skjælvende Længsel« er blevet til 
»Drømmenes sælsomt skiftende Røg«, der »Flakker og hvirvles afsted«, en udvikling fra en vagere, vegeterende mellemtilstand til en hidsig, hvileløs uro.

Hvad er det da, der sker i den glødende nat neden for den højtliggende balkon, hvor gardinets kolde silke blot vugger i sine tunge folder? Svaret findes i eksklamationerne i linierne 6 og $7 \mathrm{og}$ i de efterfølgende liniers retoriske spørgsmål, og det gives i negationernes form. Hvad der hersker og udfoldes i den glødende nat, er det modsatte af bevidst vilje: " - Viljer er Voks i din bløde Haand«(v. 6). Og det er det modsatte af troskab: »Og Troskab Siv kun for din Aandes Pust« (v. 7). Det kaster klogskab omkuld: „Og hvad er Klogskab lænet mod din Barm?«(v. 8). Og det forfører uskylden: »Og hvad er Uskyld daaret af dit Blik«(v. 9), der er blindt, vildt, tømt for bevidsthed og magtfuldt som driften uden tømme: „Vældige blinde, Mænade« (v. 14). Bølgens metamorfose til 'glødende nat' fortsætter gennem samme nu velkendte metonymiske proces til alt det, der sker i en sådan nat. Det har en umiskendelig sexuelt lidenskabelig farvning: hovedet, der mister besindelsen »lænet mod din Barm«, og uskylden der »daares af dit Blik«. Og den direkte mænade-reference - Dionysos-togets følge af vilde, lidenskabelige kvinder - sammenfatter det i en gentagelse af antikallusionerne. Fra de drukne mænader og Dionysos går også forbindelsen tilbage til 'bølgens' tidligere landing og død i vinløvet og drueklaserne. Samtidig læses selve bølgemetaforen ind i lidenskabelighedens traditionelle blodmetafor og etablerer, garneret med en varme-kulde-symmetri og via en sammenligning, en anden forbindelse helt tilbage til første strofes »Bølgers Verden«: »suger vildt/ Til Stormflod Aarens røde Strøm,/Som Maanen suger Havets kolde Vande« (v. 10-12). Heri ligger endelig også blikket, der ved at »suge vildt«og "suge« blodet til en stormflod, aktiverer elementer af både et malstrøm- og vampyrbillede i ét. Som tidligere er der også i disse linier rigt med allitterationer og assonanser samt anaforer til at akkompagnere det tætmaskede net af billedlige relationer, der gennemvæver beskrivelsen.

Den tematiske forskydning fra den foregående strofes latente stadium af "Angst« og »Længsel« til den nu udfoldede lidenskab korresponderer med markante forskydninger i deskriptionen og af de sensoriske felter, den fremhæver. Den langsomme, glidende bevægelse fortsætter endnu i den første beskrivelse af 'den': »Langsomt glider du henover Jorden« (v. 2). Men allerede i næste linies »sælsomt skiftende Røg«, der »Flakker og hvirvles afsted " begynder dynamikken at intensiveres. Kraften, der rejser sig, er stærk som himmellegemernes gravitation: "Som Maanen suger Havets kolde Vande«. Samtidig er bevægelsen imidlertid blind og uforudsigelig, som det understreges i det gentagne "sælsomt", først i vers 3, derefter dobbelt i vers 16's allitteration: »Sælsomme Bølger af sælsom Lyd». Blindheden modsvares her 
af et drastisk skift, hvor lydsansningerne for første gang i digtet rykker i forgrunden. 'Den' - bølgen - der i første strofe stod visuelt frem som en stejlende ganger og i anden strofe associeredes med de duftende luftninger, er nu direkte blevet til lydbølger, der i et slående synæstetisk billede er så stærke, at de »blinker og skummer« (v. 15). Blindheden og den voldsomme lyd er igen koblet med den mænadelignende drukkenskab: „Bægeres Klang« (v. 17). Men hvor moderationen, troskaben og uskylden er døvet, "synger« til gengæld kraften, volden og dermed døden, i fiktionens italienske renæssanceunivers samlet i et 'kårde og kappe'-billede, hvori al dæmpet dvælen er afløst af hård og hidsig handlen: "Staalets hurtige, syngende Klang, / Blodets Dryppen og Blødendes Rallen/ Og tykmælt Vanvids Brølen« (v. 18-20). Men digtet lader ikke linien til det sexuelle fald, som indledte strofens handlingsbeskrivelse, være underforstået, i kampens brølen blander sig lige så lydeligt "purpurrøde Attraaes hæse Skrig...»(v. 21) Således munder dynamikken med strofens stærke skred ud i den gotiske traditions klassiske sammenkædning af sex, vold og død. Dog ikke på en måde, der peger ud over teksten, væk, men på et underliggende lyd- og billedplan indad mod digtets tematik og tidligere anvendte troper. Den bølge, der i første strofe rejste sig og tog land, slutter her en cirkulær bevægelse, idet den ender som »Blodets Dryppen« ned indtil døden. Den dødsrallen, som rejsningen samme sted i teksten startede med at negere, ender her til sidst med alligevel at finde sin ordrette bekræftelse i »Blødendes Rallen«. Mens attråens »hæse Skrig...» med sine tre prikker gentager med at pege mod udgangen i døden og tilintetgørelsen, knytter det "purpurrøde« samtidig linien tilbage til »Aarens røde Strøm« (v.11), til sammenligningsleddets »Vande« (v.12) og derfra direkte videre til til den første digtlinies 'bølge'.

Men netop som cirklen er sluttet, og bølgen efter at have endt sine mange metamorfoser nu i blodets form er rallet tilbage til det oceaniske udgangspunkt, hvor hele bevægelsen startede, viser den sig alligevel at indeholde eller have frembragt en 'rest': "Sukket«. Også 'sukket' "svulmer og døer» (v.23) ligesom bølgen. Og - igen ligesom bølgen - er det en størrelse, der "døer for at fødes paany«(v.24). Den store cirkel, som bølgen ved sit metamorfoseforløb gennem stroferne aftegnede, spejler og gentager således digtbegyndelsens lille cirkel, hvor bølgen kun tog land for langsomt at sive „Rallende med Grusets Perler, /Atter ud i Bølgers Verden.» Forskellen er kun »Sukket« og med en vis logik stilles det apostroferende til natten: »Sukket du glødende Nat? « Det er først i den glødende nat, bevidsthedsrørelserne vilje, troskab og klogskab overhovedet er kommet ind i tekstuniverset, der indtil da har været domineret af natur, flora og fauna. Og selv om lidenskaben og drifterne fejer sartere rørelser til side, er det alligevel i en vis forstand deres egne ledsagefænomener. Sukket, der svulmer, er en sorgfuld efterkom- 
mer af den længsel, der »skjælvende« søgte frem for senere at ende i tredje strofes orgier. I den store naturproces, der opridses, er de moralske størrelser et sideprodukt i forhold til den "purpurrøde Attraaes hæse Skrig« og "Aarens røde Strøm«. Men det smertefulde suk, som de destillerer sig til, når de som afmægtige vidner overværer, hvorledes »Aarens røde Strøm» ender i »Blødendes Rallen«, er dog et spørgsmål værd: „Men Sukket glødende Nat?«

Næste strofes svar herpå er ikke et svar, men en række hypoteser og nye spørgsmål. Det afgørende heri er imidlertid et markant tematisk skift indeholdt i deskriptionen, der nu griber tilbage til den tomme balkon højt svævende over de 'sælsomme' excesser, som den nedfældede bølge ved villaens fod endte med at brænde sig selv op i, indtil kun liderlighedens skrig og dødens rallen var tilbage. Balkonens tunge, vuggende silkegardiner, der standsede bølgens »skjælvende Længsel« frem mod villaens indre, antager gennem en ny metonymisk metamorfose nu mere tydeligt selv bølgekarakter, og forskydningen indebærer en åbning for det, der før var lukket: „Gardinets Silkevover skilles«(v.1). Ikke kun ud fra en bred teksthistorisk ramme, men i særdeleshed ud fra digtets egen forudgående tematiske bevægelse er det, der åbenbarer sig i det inderste indre, ikke overraskende en kvinde, tilmed »en Kvinde høj og Herlig« (v.27). Fra 'bølgens' begyndelse som en stejlende ganger, over dens senere anelser og længsler og til dens afsluttende falliske udfoldelser med 'stålet' er dens maskulinitet blevet tilstrækkelig markeret. At kvinden tilsvarende nu træder frem for enden af forløbet som gåden og måske svaret bag den skildrede maskuline bevægelse er et konventionelt træk. Det er naturligt kvinden, hvortil 'sukket' og dets spørgsmål stiger op.

Men lige så konventionel figuren er, lige så særegen og metaforisk kraftfuld er dens udformning: "Tegner mørk sig mod den mørke Luft« (v.3). Endnu mere frontalt end tidligere negerer teksten netop på dette afgørende sted en realistisk-referentiel læsning. Den danner et billede, der kun kan dannes i sproget. Det kan skrives og siges, men ikke findes. Ganske vist ville man kunne konstruere hypoteser om, at figur og baggrund har forskellige grader af 'mørkhed' og derved kan skelnes. Eller man kan argumentere sproginternt logisk: hvis ikke figur og baggrund på én eller anden måde kan skelnes, er udsagnet ikke meningsfuldt, forstået som logisk konsistent. Men en digterisk tekst er ikke forpligtet på logikken, som blot er ét bestemt sæt sproglige spilleregler. $\mathrm{Og}$ man ville udmærket kunne argumentere for, at den relevante betydning netop ligger i denne mærkelige sproglige figurs trods mod både logik og referens: når den mørke figur »tegner« sig mod den mørke baggrund, kan det læses som et billedligt udsagn om, at villaens indre er 'tomt'. Transcendensen, hvis sted befinder sig bag sløret højt svævende over det smertefulde jordiske liv, findes ikke, ses ikke. Rummet er tomt. Eller 
mere sofistikeret: vi ved ikke, om den findes eller ikke findes. Om det mørke, der tegner sig mod det mørke, er en fantasme på linie med det, der skabes i de efterfølgende apostrofer og de ubesvarede spørgsmål til den apostroferede: »Hellige Sorg i dit Blik« (v.4) og frem til »Er det din Tanke, høje Kvinde.«Om det, der 'tegner' sig egentlig er et tegn, eller det er ingenting; et 'noget', der intet betyder.

Alle disse spørgsmål og uvisheder ligger som muligheder i dette mærkelige sproglige billede, der er mere interessant end de efterfølgende vers' (421) mange hypotetiske tolkninger af, hvordan dette virtuelle tegn måske skal læses. Digtet slår nemlig her for første gang over i at formulere sin tematik ikke i stærkt ladede deskriptioner og et komplekst billedsprog, men i direkte filosofiske, begrebsmæssige spørgsmål: »Hvorfor Livet?/ Hvorfor Døden?/ Hvorfor leve, naar vi dog skal døe« etc. De kan lyde som en parodi, men er det vel næppe. Tværtimod, apostrofernes lyriske jeg - „Jeg kjender din Flugt, du flyvende Bølge« - ekspanderes i disse spørgsmål og anråbelser til et eksistentielt 'vi'. Trods deres almene, tynde begrebslighed har de nemlig en tæt og synlig forbindelse direkte tilbage den tematik, teksten på sine andre sproglige niveauer indtil da har udviklet. De er da også helt indvævet i det allerede etablerede billedsprog. 'Sukket', der i det hypotetiske udkast bliver til 'sorg' - både hellig og »haabløs« (v. 6) - 'brænder' ligesom den 'brænden', der er det centrale billede i strofe 3 . Metaforen varieres og tydeliggør i »disse Baal af Kval og Smerte« (v. 19) yderligere, hvad strofe 3 fortalte. Bølgemetaforen, der går gennem hele teksten, gentages også og knyttes igen direkte til beskrivelsen af den cirkulære, biologiske proces: »Slægter paa Slægt i lange, mørke Bølger« (v.10) ligesom bølgebevægelsens repetitive karakter, der i første strofe var en 'rallen' tilbage til startpunktet, nu gentages som en rullen: »Rulle over Jord/ Rulle og forgaa» (v.11-12).

Sværdbilledet gentager tredje strofes 'syngende stål', og det bliver også her kombineret med et 'kårde og kappe'-billede af livets kamp, ikke mindst den forgæves kamp mod døden, som det i sidste ende munder ud i: „Hvorfor kæmpe, naar vi veed, at Sværdet/ Dog skal vristes af vor Haand en Gang?« (v.17-18). Og 'sukket', der blev til 'sorgen', expliciteres nu endnu stærkere til 'liden’: »Tusind Timers Liv i langsom Liden, / Langsom Løben ud i Dødens Liden?«(v.20-21).

Ligesom de foregående strofers centrale billeder således samles og bygges over med en tydelig filosofisk udlægning, således intensiveres ikke mindst i de sidst citerede vers også de mønstre, som i de forudgående strofer sensorisk har akkompagneret og på et udtryksplan gentaget den indholdsmæssige repetitionstematik. Svulmende kæder af allitterationer og assonanser kombineres og krydses tæt, og de mere moderate anvendelser af anafor i de foregående strofer, afløses af et voldsomt, ja bombastisk firedobbelt 'hvorfor' 
afsluttet af et 'hvortil'. Det er en strofe, hvis kadence er som en højromantisk, dyster sørgemarch, en 'marche funèbre' à la Beethoven.

Men digtet slutter ikke med denne sorg over, at bølgens rejsning alligevel kun fører til livets liden og i sidste ende dets ‘dødsrallen’ tilbage til udgangspunktet igen. Sorgen står kun som anråbende spørgsmål. Og skønt kvinden fra gardinerne, der skiltes, i den sidste korte strofe nu synes at være kommet frem på balkonen, er tegnet stadig lige uudgrundeligt: »Tavs og rolig staaer hun paa Balkonen, /Har ej Ord, ej Suk, ej Klage.«(v.1-2). Hun tegner sig - i en identisk gentagelse af ordlyden - stadig 'mørk mod den mørke luft' med den uvished, dette billede indeholder. Men et nyt billede føjes i en sammenligning til: „Som et Sværd igennem Nattens Hjerte« (v.4). Dette billede alene er svaret. Eller rettere: det svar, som 'hun' giver. For selv om 'hun' - ud over at hun 'tegner sig'- »Har ej Ord, ej Suk, ej Klage«, så står det lyriske jegs sukkende og sorgfulde anråbelser stadig udementerede, intakte tilbage. Som før svarer teksten på sine spørgsmål ved at slå over i billedladet deskription med de flertydigheder, det nødvendigvis implicerer. Og lige så potenseret dette billede i kraft af sin slutplacering er, lige så komplekst er det. Én enkelt betydning er dermed udelukket. Men hvilke betydninger kan den forudgående tekst og analysen af den pege på?

'Hjerte' har ikke optrådt i andre forbindelser tidligere i teksten, og det konventionelle enderim på 'smerte' er naturligvis heller ikke manifest. Til gengæld ligger en anden, latent sammenkædning med anråbelserns 'suk' og 'sorg' ikke fjern: hjertesuk og hjertesorg. Og da både sukkene og sorgen så udtrykkeligt har været forbundet med 'natten', vil det være naturligt at læse "Nattens Hjerte« som en metonymi for sukkene og sorgen, så meget mere som netop disse ikke helt almindelige metonymiske forskydninger er grundlæggende for tekstens billedsprog. Også sværdet »igennem Nattens Hjerte« er forbundet med en metonymisk kæde, men i modsætning til 'hjerte' som en størrelse, der flere gange forinden har været manifest. Begyndelsen til sværdbilledet starter i første strofes ridder- og kampassocierende beskrivelse af bølgen som 'stejlende ganger'. Om natten møder vi sværdbilledet mere direkte i »Staalets hurtige, syngende Klang« (v.18). Og endelig står det i fjerde strofes anråbelser helt centralt som billede på den bølgeoprundne livsog kampkraft, der i disse linier tilmed knyttes op på et eksistentielt 'vi': »Hvorfor kæmpe, naar vi veed, at Sværdet/ Dog skal vristes af vor Haand en Gang?« Overgangen fra dette sværd til, at balkonens kvinde "Som et Sværd» går gennem nattens hjerte, er da den ultimative metonymiske metamorfose af den art, som teksten tidligere har benyttet: efter at have været $\mathrm{i}$ "vor Haand« - som må give slip - bliver det til sidst et billede på 'kvinden', ja i sin handling - »igennem Nattens Hjerte« - identisk med hende. Kæden af metonymiske metamorfoser kulminerer for at afslutte i en metafor. 
For en læsning, der ikke vil afkode billedsproget reduktivt ved at omskrive det til vor dagligdags og -sprogs standardkausaliseringer, vil det være en pointe at fastholde muligheden for, at det ikke dermed er kvinden, der vrister sværdet ud af vor hånd. Det kan være en tænkelig forbindelse, og modsætningen mellem det maskuline 'vi' og den fremmede, gådefulde kvinde er rigeligt institueret i de forudgående anråbelser, ligesom sammenkædningen med en aktiv (kvinde) vs. passiv (mand)-modsætning findes andre steder hos Jacobsen. ${ }^{12}$ Sværdet kan imidlertid også læses som bølgens ultimative eksistensform og slutbilledet følgelig som dens - og alt det, den kan betyde - harakiriagtige selvdestruktion. Dog vil denne sidste læsning alligevel være nødt til at fastholde den iøjnefaldende kønsdeling, der starter, allerede da de sukkende spørgsmål første gang fremkalder billedet af en "Kvinde høj og herlig", et billede, som forbliver intakt, idet det stadig er hende, der igen til sidst 'tegner sig' gennem nattens hjerte.

Med forbehold for de mange flertydigheder og åbenheder, der ligger fastholdt i selve digtets tæt billedsproglige karakter, vil man på et relevant generalisationsniveau kunne hævde, at dets tematik er den mandlige drift, til den ene side ført tilbage til en bred biologisk-naturmæssig oprindelseshistorie, til den anden side overbygget af en hjemløs sorg over dens og livets repetitive rejsning og hver gang lige smertefulde død. En mening med denne gentagne livscyklus er ikke synlig. Kvinden står på én gang som det aldrig nåede mål for rejsningen og som udenforstående tilskuer til dens rallende død, ufortolkelig og paradoksalt dog alligevel - i sit 'mørkt mod mørkt' tydelig som »et Sværd igennem Nattens Hjerte«.

Denne tematik kan perspektiveres både i forhold til forfatterskabet og i forhold til brede litteratur- og kulturhistoriske tematikker af beslægtet karakter. Sat i forhold til litterærhistoriske præferencer er det synligt, at digtet i sin fiktions- og billedverden skatter til den renæssancefascination og de 'kårde- og kappe'-fiktioner, som hen over midten af det 19. århundrede blev populære, bl.a. i interessen for historiske romaner, som også hørte til Jacobsens felt. Arabesk- og Michelangelo-referencerne er del heraf. Det er træk, der kan karakteriseres som senromantiske, måske tidligt symbolistiske. Særegen og uden for den brede strøm er imidlertid digtets konsekvente brud ikke kun med rim og metrum, men også med de normale fiktionsverdener, hvor afgrænselige og menneskelige karakterer optræder i kohærente

12. Der findes i flere Jacobsen-tekster, bl.a. i Fru Marie Grubbe og i novellen "Et Skud i Taagen", en figur, som man i psykoanalytisk terminologi ville kunne kalde 'den falliske moder'. Omvendt er der naturligvis også mange eksempler på maskulin sadisme og feminin masochisme ikke mindst i Fru Marie Grubbe. De fleste af digtets billedsprogselementer, sværdmetaforikken, kårde- og kappefiktionen m.m., findes ligeledes andre steder i forfatterskabet. Jeg har behandlet en del af disse billeder i Interieur fra det 19. Arhundredes borgerlige kultur, Kbh. 1976. 
tid- og rumkonstruktioner. Selv den lyriske digtning har, trods afstanden til den realistiske prosa, både før og efter 1875 sine "realistiske« konventioner. I forhold til "Arabesk« er alle gængse, kausalt orienterede forståelsesmønstre imidlertid slet bevendte. Det er på det plan meget uklart, hvad der egentlig foregår, og hvem der handler. Til gengæld kan det vanskeligt overses, at der ikke desto mindre foregår meget. $\mathrm{Og}$ sættes analysen ind på et billedsprogligt plan, er det muligt at finde et fuldt kohærent dynamisk mønster i det, der her er blevet beskrevet som digtets kæde af metonymiske metamorfoser, frem til en afsluttende metafor, der er tom.

\section{III}

Sammenholder man metonymiernes dominans i billedssproget, tekstens tematik og dens hele bevægelsesmønster, der drives af metonymisk udløste forskydninger, melder sig flere teoretiske tolkningsrammer og perspektiver, som det vil være nærliggende at tage under overvejelse. Dette bliver da emnet for denne artiklens tredje og sidste del.

Lacan forbinder i sin lingvistisk inspirerede Freud-læsning metonymien med det psykoanalytiske begreb om forskydning: for at omgå censuren kan det ubevidste finde udtryk ved sprogligt at forskyde sig fra én udtryksstørrelse - en signifiant - til en anden, der er forbundet med den første gennem nærhed; altså ved at benytte en metonymi. På et mere generaliseret niveau beskriver han også selve begæret som grundlæggende metonymisk. Det forskyder sig hele tiden fra objekt til objekt i samme forstand som sprogets signifianter er en uendelig kæde af nærhedsrelationer. Han taler også om »dets "perverse« fiksering til det selvsamme punkt i signifiant-kæden, hvor dækerindringen stivner, og hvor fetichens fascinerende billede oprejser sin statue «. ${ }^{13}$ Skønt eller måske netop fordi disse formuleringer ikke just er klare i deres betydning, synes de i et vist omfang at sige noget om digtets metonymiske kæde, ikke mindst måske dens afslutning i billedet af ' $\mathrm{k}$ vinden som et sværd gennem nattens hjerte'. Her bliver tekstens metonymiske kæde endelig standset og lukket. Men hvor en romantisk farvet 1800-talsdigtnings vanlige metaforer for kvinden og kærligheden normalt lukker de metonymiske kæder ved i sidste ende - 'opad' og væk fra kæden - at pege mod en transcendens af naturmæssig eller guddommelig karakter, vender denne slutmetafors kombination af hjerte, sværd og nat i stedet 'indad'. D.v.s. den peger tilbage mod den forudgående kæde, hvis successive variationer af

13. "Bogstavets instans i det ubevidste«, in J. Lacan: Det ubevidste sprog, København 1973, p. 108. 
'sværd'- og 'hjerte'-elementer - gennem et solomløbs cirkulære bevægelse fra morgen til nat - til sidst samles i ét billede på en destruktion, der i sin suicidale introversion fastholder det metonymiske grundlag. Sværdet og hjertet slutter som i næsten bogstavelig forstand døde metaforer. Transcendensen er i denne metaforbrug demonstrativt tom, kunne man sige med reference til Hugo Friedrichs teori om den moderne lyrik. ${ }^{14} \mathrm{Og}$ således kunne man substantialisere Brandes' Jacobsen-epitet 'moderne', såvel som egentlig også retfærdiggøre karakteristikken af digterens praksis: »at Formen paa ethvert Punkt skal rette sig efter Følelsen«.

Lacans inspiration til at inddrage metonymien i sin lingvistisk formulerede Freud-genlæsning er naturligvis grundteksten for hele den nyere tænkning om metonymi, nemlig Roman Jakobsons klassiske, skoledannende $»$ To aspekter af sproget ... $\aleph^{15}$ Det var heri metonymien for første gang for alvor blev løsrevet fra retorikkens og stilistikkens tropologiske redskabskasse og $\mathrm{i}$ ét genialsk greb blev indsat i en symmetripræget modsætningsrelation til metaforen samtidig med, at de to 'mestertroper' med denne relation fastholdt blev plottet ind på hver sin akse i den strukturelle sprogvidenskabs dybestliggende anskuelsesmodel: syntagme vs. paradigme. Sammenføringen af metonymien og sprogets syntagmatiske akse var og er også en langthen frugtbar ide, og en argumentation, der lægger vægten på kontiguitetens, nærhedsrelationens, dominans i både metonymien og på sprogets syntagmatiske akse har også et stærkt kort på hånden. I syntagmet står tegnene i kæde ved siden af hinanden, det er deres manifeste nærhed, der gennem kombination frembringer og bærer den konkrete betydningsdannelse. Tegnenes relationer til de manifestationsmæssigt fraværende paradigmer er i sammenligning hermed fjerne, usynlige: det er kun de selekterede størrelser blandt paradigmets mange mulige, som faktisk kan ses, resten spiller kun med i betydningsdannelsen in absentia.

Men alt går ikke restløst op i denne sammentænkning. Jakobson formulerer dette på en måske lidt eufemistisk måde, når han skriver, at interaktionen mellem den metaforiske og den metonymiske funktion i sproget er »særlig udtalt« i den litterære kunst (»ToA«, p.61). Og han tilføjer, at da begge funktioner kan forekomme "på et hvilket som helst sprogligt plan morfemisk, leksikalsk, syntaktisk og fraseologisk - skabes der en imponerende række af mulige konfigurationer. Hver af de to graviterende poler kan være fremherskende« (»ToA«, p.62). Han viser ud mod de store linier i litte-

14. Jfr. Friedrich: Strukturen i den moderne lyrik, Fredensborg 1968.

15. Jakobson: »To aspekter af sproget og to typer afatisk forstyrrelsen«, in $K \& K 78$ (1995) (herefter forkortet »ToA»). 
raturhistorien og eksemplificerer ved at nævne russiske lyriske sange og russiske helteeper som eksempler på modsat 'gravitation'.

Men heller ikke hvis man går den modsatte vej tilbage til de retoriske fænomener og termer, tegner billedet på andre niveauer helt enkelt, hvilket et kort blik på synekdoken - del for helhed - kan vise. Synekdoken opfattes traditionelt som en særlig - og fremtrædende - form for metonymi. Men nærheden mellem f.eks. hånden i et manifest metonym og den hele person eller krop, som denne synekdoke står for, vil ofte være kun tankemæssig, uden base i nogen syntagmatisk nærhed. En sådan metonymi kan meget vel anskues som værende lige så paradigmatisk i sin måde at danne betydning på som nogen metafor. På grund heraf at udskille synekdoken fra tropen metonymi kan måske friste, men løsningen kan let blive kortfristet, og det er heller ikke i den retning, Jakobson peger. Men meget synlige gråzoner mellem metafor og metonymi træder nemt frem for en nærmeregående undersøgelse, og bataljer i slægt med dem, retorikkens klassiske 'folie de classification' gav anledning til, kan bryde ud. ${ }^{16}$ Jakobsons model, der placerer metonymien i syntagmet, har en genialsk anskuelighed som sin force. Men på manifestationernes niveau bliver det som generelt med hele forholdet mellem metafor og metonymi noget mere mudret. Eller mere konstruktivt formuleret: hvis emner skal beskrives nuanceret, må analysen hele tiden foretage vanskelige strategiske valg, der ret beset ender med at efterlade de helt generelle modeller i en lemlæstet skikkelse eller i hvert fald med en modificeret udsagnsværdi.

Meget vel kan noget sådant have været medvirkende til, at Jakobson nøjes med et helt oversigtligt anslag, hvor han skal udmønte sit synspunkt på foreliggende litterære tekster, hvilket han interessant nok gør litteraturhistorisk. I en formulering, som siden har fået en slags referencestatus, skriver han:

"Den metaforiske proces' forrrang i romantikkens og symbolismens skoler er gentagne gange blevet erkendt, men det er stadig utiltrækkeligt indset, at det er menonymiens overvægt, der ligger til grund for og faktisk forudbestemmer den såkaldte 'realistiske' retning, der tilhører et mellemliggende stadium mellem romantikkens undergang og symbolismens fremkomst, og som er i opposition til begge. Idet han følger kontinuitetsrelationernes sti, foretager den realistiske forfatter digressioner fra handlingen til atmosfæren og fra personerne til omgivelserne i tid og rum. Han er glad for synekdokiske detaljer. I scenen med Anna Kareninas selvmord er Tolstojs kunstneriske opmærksomhed fokuseret på heltindens håndtaske» (»ToA«, p.62).

16. Jfr. Roland Barthes: »Den gamle retorik«, in $K \& K 84$ (1997), p. 77 og passim. 
Eksemplifikationen og henvisningen til den russiske litteraturhistorie er illustrerende, men det indflettede, meget stærke udsagn - »det er menonymiens overvægt, der ligger til grund for og faktisk forudbestemmer den såkaldte 'realistiske' retning « - turde nok udsættes for en nærmere prøvelse. Især ordet 'forudbestemmer' præsenterer en interessant og vidtgående hypotese. Jakobson nøjes i den citerede forbindelse dog med anslaget og uddyber heller ikke i andre sammenhæng tanken eller empirien med mere end antydninger. ${ }^{17}$ Men det er en måske interessant detalje, at netop synekdoken står i forgrunden det sted, hvor han vil knytte forbindelsen mellem metonymien og den realistiske prosa. Hans forslag er reelt at opfatte den fyldige deskription i den klassiske 1800-talsrealismes prosa som retorisk set udøvende synekdokiske funktioner. Tolstojs beskrivelse af håndtasken er indirekte - gennem del for helhed - en beskrivelse af Anna Karenina. Og kunne man fortsætte tanken - beskrivelsen af protagonisterne i denne slags tekster er synekdoker for beskrivelsen af typer, køn, hele sociale grupper. Fortsættelsen til det sidste niveau ville være helt i tråd med Tolstojs egen opfattelse, sådan som han udfolder den fyldigt netop i Anna Karenina. Den ville også være i overensstemmelse med klassisk realismeteori af den art, som udvikles i Georg Lukács 'typebegreb', ${ }^{18}$ og som ligger allerede i den litteraturkritiske diskurs i slutningen af 1800-tallet, eksempelvis hos Brandes og bag ham hos Taine. ${ }^{19}$

Følger man synekdokesynsvinklen i retningen indad mod de snævrere tekstinterne sammenhæng, kan man teorihistorisk - uden det samme retoriske udgangspunkt og vokabular som Jakobsons - se den implementeret i én udformning i den tematiske kritik hos Jean-Pierre Richard i 1950'erne og senere i en anden udformning i A.-J. Greimas' strukturelle semantik; eller måske tydeligere i den Greimas-inspirerede danske udformning af den tematiske analyse. I alle disse sammenhæng fungerer den metonymiske nærhed mellem elementerne, hvad enten det er i den tekstlige kæde og/eller i det beskrevne fiktionsunivers, som indgangsdør til hele det omfattende mønster af betydninger, der går på tværs gennem teksterne henover grænserne mellem person og ting og mellem dialog og deskription. Både metonymien $\mathrm{i}$ almindelighed og synekdoken i særdeleshed kan siges at være givtige til at anskue den realistiske prosas måde at danne betydning på, et godt greb til

17. Bygger på en gennemgang af Roman Jakobson: Selected Writings, I-VIII, Haag 1962-1988, med 'metonymi' som indexord.

18. Georg Lukács: Essays om realisme, 1-2, Kbh. 1978.

19. Jeg sigter her til, at Brandes læser et folks litteratur som synekdokisk repræsenterende "dets Anskuelsers og Følelsers hele Historie«, og Taine tilsvarende i en nationallitteratur ser "la psychologie d'un peuple«, jfr. min Teoriens topik, Kbh. 1998, p. 70 f. 
analytisk at komme bag realismens overflade af virkelighedsgengivelse, det være psykologisk eller i fiktionens tid/rum-dimension.

Af dette følger imidlertid ingenlunde nogen bekræftelse på Jakobsons hypotese om metonymien som 'forudbestemmende' for realismen eller for den sags skyld som blot 'tilgrundliggende' for den. Dog vil det sidste givetvis være lettere at sandsynliggøre end førstnævnte formulering, der sikkert kan læses som en overbudsformulering fremkaldt ved afsmitning fra den naturvidenskabeligt-medicinske diskurs i den øvrige del af Jakobsons artikel; d.v.s. i sig selv et metonymisk fænomen.

Den anden fejlslutning, som kunne udgå fra Jakobsons formuleringer og fra det, som synes at bekræfte dem, er den tanke, at metaforens angivelige 'forrang i romantikkens og symbolismens skoler' skulle indebære, at metonymierne sammesteds er få eller uinteressante. Ud over at være et problematisk, om end i sammenhængen nærliggende, ræsonnement, kræver det i hvert fald mere litteraturhistorisk empiri end den generelle henvisning til, at metaforens forrang 'gentagne gange er blevet erkendt'. Dertil peger det på et tredje, allerede antydet problem i Jakobsons fremstilling. Det er, at den meget anskueliggørende, kontrastive beskrivelse af metafor og metonymi og sammenknytningen af disse med sprogets paradigmatiske og syntagmatiske dimensioner, som i høj grad forstærker modsctningen, i realiteten kan spærre for undersøgelsen af ligheder og forbindelseslinier mellem metafor og metonymi. Når Jakobson omtaler deres 'interaktion', er det en interaktion mellem kræfter som grundlæggende 'graviterer' i hver sin retning. Måske er det en problematisk metafor, som her løber af med tanken.

Det er heller ikke den tråd, der bliver fulgt hos Peter Brooks, når han i Reading for the Plot udvikler sin anvendelse af metonymibegrebet. Han refererer sig naturligvis til Jakobson, men går ikke ned i dennes egentlig lingvistiske tankegang. Derimod ekspanderer han - på karakteristisk vis, når man tænker på bogens amerikanske 1984-kontekst - Jakobsons i forvejen generaliserede betragtninger over metonymiens dominans i 1800-tallets realistiske prosa til en sammentænkning med 'det narrative' i den bredeste forstand overhovedet. Brooks opfattelse af det narrative er stærkt eksistentielt forankret og farvet, ${ }^{20}$ samtidig med at det er baseret på en Lacan-inspireret psykoanalyse. Metonymien bliver i hans konception således et begreb for begærets stadige forskydning fra det ene objekt til det næste i en stadig jagen efter en mening, som det hverken kan nå frem til eller udsige: »Narrative is

20. "It is my simple conviction, then, that narrative has something to do with time-boundedness, and that plot is the internal logic of the discourse of mortality ", Brooks: Reading for the Plot, N.Y. 1985 (org. 1984) p. 22. Dansk: "Det er således min enkle overbevisning, at fortælling [narrative] har noget at gøre med tidsbundethed, og at plot er den interne logik i dødelighedens diskurs». 
hence condemned to saying other than what it would mean, spinning out its movement toward a meaning that would be the end of its movement ${ }^{21}{ }^{21}$ skriver han i en sammenfatning af, hvordan han mener Lacan fortolker metonymien. Han eksemplificerer også senere litteraturhistorisk, nemlig med en henvisning til Stendhals Julien fra Rødt og Sort, som han mener "typifies the highly metonymic character of the Stendhalian hero, figure of unarrested, unappesable desire which can never be anchored in a definitive meaning, even retrospectively ${ }^{22}{ }^{22}$ Julien er et »self-inventing artifact«.

Dette metonymikoncept er reelt helt anderledes end Jakobsons, især når man tænker på dennes mest konkrete litterære udmøntning: beskrivelsen af prosarealismens deskriptionselementer som synekdokiske. Dog ender det alligevel med, at Brooks - denne gang via Freuds forestilling om repetition i Jenseits des Lustprinzips - får peget på en dimension af den indre forbindelse mellem metonymi og metafor. I romanheltens stadige begærdrevne handlingskæde af metonymiske forskydninger opstår alligevel mønstre af gentagelse. I denne gentagelse genereres mening, som ender med tilbagevirkende at illuminere teksten som en helhed: vi får mulighed for at opfatte teksten som én total metafor -»but not therefore to discount the metonymies that led to it. ${ }^{23}$

Netop med disse sidstnævnte formuleringer kan det undre, at Brooks ikke refererer til Gérard Genettes analyse af forholdet mellem metonymi og metafor hos Proust. ${ }^{24}$ Niveauerne er meget forskellige. Brooks taler generelt om narrative forløb og disses lukning til helheder med metafor-karakter. Genette formulerer sig om funktioner i den tekstlige kæde i Prousts prosa ud fra en mikroskopisk orienteret, meget konkret analyse. En af hans konklusioner er, at metaforerne hos Proust hviler på de metonymiske kæder; at den metonymiske nærhed er nødvendig for, at metaforen kan opstå. $\mathrm{Og}$ omvendt får de metonymiske kæder først 'soliditet' - for ligesom Genette at sige det med et Proust-udtryk - i kraft af metaforiske relationer. Henover formulerings- og tankemæssige niveauforskelle er det en meget beslægtet opfattelse af interaktionen mellem metafor og metonymi, der her bliver udtrykt. $\mathrm{Og}$ som - à propos - peger i en anden retning end Jakobsons gravitationsmetafor, skønt Jakobson også bruger termen 'interaktion', og skønt

21. Dansk: „Fortællingen er således dømt til at sige noget andet end den gerne ville betyde, idet den udspinder sin bevægelse hen mod en mening, som ville være slutningen på dens bevægelse«, op.cit., p. 56.

22. Dansk: »er typen på Stendhal-heltens højst metonymiske karakter, en skikkelse styret af ustandseligt, hvileløst begær, som aldrig kan forankres i en definitiv mening, ikke engang retrospektivt«, op.cit. p.76.

23. Dansk: "men ikke for af den grund at afskrive de metonymier, som førte frem til den«, op.cit., p. 108.

24. Genette: »Metonymi hos Proust«i dette nummer af $K \& K$. 
hverken Genette eller Brooks overdrevent pointerer nogen afstand til Jakobson.

Imidlertid er det med en Genette-farvet anskuelse - Brooks' formuleringer er oftest for abstrakte - af den intime forbindelse mellem metaforiske og metonymiske funktioner, jeg nedenfor kort vil vende tilbage til Jacobsendigtet. Dog vil jeg ikke gøre det uden undervejs at pege på, at den form for interaktion mellem metafor og metonymi, Genette fremanalyserer i Prousts tekst, efter min mening kan ses som kun en konkret, om end meget interessant version af et mere generelt forhold mellem den syntagmatiske og paradigmatiske akse i sproget. Det er sjældent, at det indses i sin fulde konsekvens, at sprogets paradigmer - på alle niveauer - grundlæggende hviler på en syntagmatisk basis: faktiske sprogmanifestationer, der forløber eller realiseres i tid. De har den dermed forbundne mangel på absolut 'soliditet'. Deres relative soliditet beror hele tiden på lukninger, som må foretages. I det dagligt talte og skrevne sprog beror den på en ensartet brugs repetition, på ordbogsdefinitioner og på konsensus herom. I det litterære værk får sproget en specifik, evt. en original prægning, der rykker det et antal grader i forhold til det fixpunkt, man prøver at fastholde igennem den nyttige, men fiktive konsensus, som 'normalsproget' er. Elementerne i det litterære værk kan ganske vist være standardmæssige: konventionelt billedsprog og genrefasthed på mange andre niveauer. Konventionsoverenstemmelsen vil da levere de nødvendige lukninger. Det ud fra et efterklassisk, 'moderne' litteraturbegreb mere originale værks sproglige særbetydninger stabiliseres imidlertid først ved den lukning, som slutningen på tekstens kæde bringer til veje. Det er denne funktion, Brooks formulerer på et generelt narrativt og psykologisk niveau, og som Genette påviser inden for rammerne af det proustske billedsprog:

"[soliditeten] kan ikke frembringes af den simple horisontale forbindelse, som er etableret i kraft af den metonymiske kæde; men man ser heller ikke, hvordan den metaforiske relations simple vertikale forbindelse skulle kunne levere en sådan. Kun ved at lade den ene skære den anden kan man friholde beskrivelsens genstand - og selve beskrivelsen - fra »tidens vilkårligheder«, d.v.s. fra enhver kontingens; kun krydsningen af en metonymisk tråd og en metaforisk kæde sikrer kohærens, tekstens "nødvendige« sammenhæng $«^{25}$

Når den metonymiske problemstilling, d.v.s. metonymiens samspil med lukninger af mere eller mindre egentlig metaforisk karakter, træder så mar-

25. Dette nr. af $K \& K$, p. 27. 
kant frem hos Proust, hænger det sammen med romanens overmætning af metonymier. De ligger ikke inden for realismens synekdokiske normalfunktioner, som Jakobson beskriver dem hos Tolstoj. Anna Kareninas håndtaske er næsten kun et sandskorn sammenlignet med beskrivelserne af klokketårnet i Combray. Men måske vigtigere endnu, den deskriptionsmæssige metonymi holdes hos Proust ikke på plads inden for rammerne af et en overordnet metonymisk kæde på handlingernes niveau i stil med den, Brooks beskriver hos Stendhal. Med bruddet i disse to henseender falder Prousts roman så meget uden for konvention og læserforventning til spillet mellem det syntagmatiske og det paradigmatiske inden for romangenren, at den for et blik som Genettes på selve billedsprogets niveau kommer til at udstille de metaforiske lukningers metonymiske base, ligesom den kommer til at udviske grænsen mellem synekdoke og metafor. Men rubriceringen af den som dermed »et prosadigt« eller som »poetisk prosa« vil, som Genette skriver, være en for grovmasket og uinteressant beskrivelse. Der er en mere specifik 'interaktion' mellem det syntagmatiske og paradigmatiske på spil.

Det sammme gælder også Jacobsens »Arabesk «. ${ }^{26}$ På selve titelniveauet signalerer den med arabeskreferencen en metonymisk uafgrænsethed, en mangel på metaforisk lukning, for så vidt som et arabesk mønster er principielt uendeligt og uden geometrisk repetition. En bevægelse i samme retning, ja et afgørende litteraturhistorisk ryk, sker ved fravalget af metrum i digtet. Set i forhold til interaktionen mellem syntagme og paradigme, mellem metonymi og metafor giver en metrisk form alene i kraft af sin repetitive karakter stabilitet og lukning, styrker det paradigmatiske. Selv den metonymisk mest udstrukne metriske form som sonetkransen lukker til sidst kæden. Omvendt åbner de 'fri vers', som Jacobsen lader flyde, i sig selv den tekstlige kæde mod metonymisk diffusion på alle niveauer, liniens såvel som strofens. Til gengæld starter allerede fra anden linie i »Arabesk« en modgående, stabiliserende bevægelse i form af den anaforiske repetition: »Tog Bølgen Land/ Tog den Land«. Og det viser sig snart, at der parallelt med den metonymiske kædes udfoldning samtidig og modgående etableres tætte mønstre af allitterationer, assonanser og anaforer. Det er et rent lydligt mønster af repetition, som med vægt kontrabalancerer de frie vers' metonymiske åbenheder. Til erstatning for den metriske fasthed opstår gennem disse lydlige mønstre allerede $\mathrm{i}$ første strofe en stabil bølgerytmes form for kontinuitet. Samtidig med at assonans, allitteration og anafor (henover-henover, fulgt-fulgt, med-med, baaret-baaret m.fl.) fortsætter, måske direkte forstærkes, begynder de metonymiske metamorfoser allerede fra slutningen

26. Jørn Erslev Andersen har i Dryssende roser, Århus 1988, p. 90 sat metonymien i forbindelse med en anden Jacobsen-tekst, nemlig det 'lyriske' prosastykke»Der burde have været Roser«. 
af første strofe at blive overlejret af en overordnet forløbsstruktur. Senest da den stejlende bølge får luftform, og lydmønstret i kæden 'flugt', 'fløj', 'flyvende’ slår bro over strofeskiftet, fremtræder tydeligt den bevægelse, der løber som tråd gennem hele digtet og ender med at binde det, d.v.s. kæden af metonymiske transformationer, sammen til et fast cirkulært mønster af repetition. Det fastholdes og varieres konstant i de lydlige mønstre, opbygges så til en døgncyklus - bølgens flugt følger døgnets gang fra morgen til nat for til sidst at rykke frontalt helt op på det tematiske niveau hvor cyklussen udvides til at omspænde enkeltlivene såvel som slægternes: „Slægter paa Slægt i lange, mørke Bølger/Rulle over Jord,/Rulle og forgaa« etc. Yderst ligger som krans om det hele billedet af selve det biologiske livs opståen fra havet og dets repetitive tilbagevenden til døden.

"Arabesk« er på alle niveauer gennemvævet af metonymier, og selve forskydningen gennem kontinguitet synes overhovedet at være den konstante dynamiske faktor i tekstens forløb. De lydlige repetitioner kommer hurtigt til, men ligesom de højereliggende cykliske figurer (døgn, liv, slægt, biosfære) hviler også de grundlæggende på metonymierne. At det tropologiske niveau, nærmere betegnet metonymien, således bliver den bærende omdrejningsakse igennem hele teksten, hænger på slående vis sammen med det demonstrative fravær af antropomorf agens på en subjektplads. Kvinden er tavs og ubevægelig, kun et udechifrerbart beskuelsesobjekt. Skyggen af et generaliseret antropomorft 'vi' dukker først op til allersidst og fremtræder da karakteristisk lidende i en kastreret synekdoke: »Hvorfor kæmpe, naar vi veed, at Sværdet/ Dog skal vristes af vor Haand en Gang«. Alligevel ender den metonymiske tråd med at blive lukket af, skåret over af en metafor, "som et Sværd igjennem Nattens Hjerte«. Det afsluttende metaforkompleks kvinde-sværd-hjerte - er paradokst, tilnærmelsesvis tomt, selvnegerende: »Tegner mørk sig mod den mørke Luft«. Det forhindrer det naturligvis ikke i at udføre sin tekstlige funktion, nemlig lukningen.

Det er i sandhed en bemærkelsesværdig tekst. Siger den måske ingen sandhed om livet - blot et bud blandt flere -, siger den i sin originalt udfoldede interaktion mellem metonymi og metafor mere om betingelserne for at danne tekstlig betydning end noget dansk digt før, måske også siden. Det bør derfor have en litteraturhistorisk placering svarende dertil.

Brandes havde ret, da han efter med at have besværet sig over den ud fra gængse synspunkter manglende sammenhæng i Jacobens romaner dog indirekte indrømmede en anden slags sammenhæng i hans 'prosalyriske' sprog: "Alt er fortættet, sammentrængt, uden Fyld eller Mellemrum.« Det kunne godt tåle at blive uddybet, og det er formentlig ikke kun i en undersøgelse af "Arabesk«, at uddybningen vil føre os til metonymien. Og i metonymien kan en helt ny tolkning og tolkningsproblematik begynde. 